\title{
NON-COMPLIANCE OF SPATIAL PLANS OF THE HIGHEST RANK IN BOSNIA AND HERZEGOVINA
}

\author{
Branislav Bijelić ${ }^{* 1}$, Dejan P. Đorđević** \\ * Urbis centar Ltd, Banja Luka \\ ** University of Belgrade - Faculty of Geography, Studentski trg 3/III, Belgrade
}

\begin{abstract}
Non-compliance of spatial plans of the highest rank in Bosnia and Herzegovina is a significant problem which has negative consequences to the territory of Bosnia and Herzegovina, which is particularly noticeable in the current debate on the route of Sarajevo-Belgrade motorway. This type of spatial plans includes spatial plans of the entities, cantons and Brčko District. This paper is an attempt to shed light on this problem by way of examining its genesis, characteristics and possible solutions. The emphasis was placed on the precise identification of the non-compliance rate of spatial plans of the highest rank in Bosnia and Herzegovina. The primary hypothesis states that the non-compliance rate of these documents is above $50 \%$. The auxiliary hypothesis states that this non-compliance is the result of inadequate legal treatment of this matter and of the non-existence of policy framework in the field of spatial planning in Bosnia and Herzegovina..
\end{abstract}

Keywords: non-compliance, spatial plan, rank, Bosnia and Herzegovina.

\section{Introduction}

Mutual compliance (conformity) of spatial planning documents is one of the fundamental principles of spatial planning (Piha, 1979), as spatial planning is observed as a mechanism of coordination and interaction (Đorđević and Dabović,

1 Corresponding author: B. Bijelić, Urbis centar Ltd, Banja Luka, Bulevar vojvode Stepe Stepanovića 101a, Banja Luka, Republic of Srpska, Bosnia and Herzegovina; email: bbijelic@urbiscentar.com 
2009). Compliance can be vertical, if based on the hierarchy of spatial planning documents, or horizontal, if related to the interrelation of spatial planning documents of the same or similar rank for the adjacent areas. It should be noted that the scientific literature generally prefers the terms vertical coordination (among different levels of government) and horizontal coordination (within the same level of government) (Faludi, 2004). That is imperative for most planning ventures (Alexander, 1992), provided that the term coordination is taken in broad sense so as to include also the other sectors and their strategic documents. This approach is also present in Bosnia and Herzegovina, where spatial plans are perceived as a framework for coordination and compliance (Bublin, 2000).

The lack of compliance or conformity of spatial planning documents can lead to their mutual non-compliance or non-conformity, which should not theoretically exist within the borders of one country. However, horizontal non-compliance of spatial planning documents poses as an obvious problem in Bosnia and Herzegovina. Actually, it stultifies the very existence of spatial planning as the practice which among other things harmonises activities in an area. This is particularly noticeable in the current debate on the route of Sarajevo-Belgrade motorway across the territory of Bosnia and Herzegovina. The entity governments are primarily in conflict because of the non-compliance of planning solutions in spatial planning documents, whereas the state government of Bosnia and Herzegovina is trying to act as a mediator in the absence of a clear and compliant planning foundation. Therefore, this paper is mainly concerned with the phenomenon of non-compliance of planning solutions in spatial planning documents of the highest rank in Bosnia and Herzegovina and it aims to find a solution to this important matter of spatial planning in Bosnia and Herzegovina. The primary hypothesis of the paper states that the level of non-compliance of these documents is above $50 \%$, i.e. that there are more non-compliant planning solutions of external character than compliant ones among spatial plans of the highest rank for adjacent areas in Bosnia and Herzegovina. The auxiliary hypothesis states that non-compliance is a result of inadequate legal treatment of this matter and of the non-existence of the political framework in the field of spatial planning in Bosnia and Herzegovina.

\section{Materials and methods}

\section{The area of study}

This research covers the territory of Bosnia and Herzegovina. As in most other complex states, the area of spatial planning is not in the jurisdiction of the state level, but of lower levels. In Bosnia and Herzegovina spatial planning is 
in the constitutional jurisdiction of the entity and canton. Such distribution of jurisdiction involves adopting laws and bylaws at the level of entities or cantons. It should be noted that the jurisdiction in the area of spatial planning in the Federation of Bosnia and Herzegovina is divided between the entity and cantonal level. Furthermore, Brčko District as a form of condominium has a full jurisdiction in the area of spatial planning on its territory (EU Floods Recovery Program, 2015).

The practical result of the spatial planning process in Bosnia and Herzegovina is the development of actual spatial planning documents. The spatial documents at the entity or cantonal level, as well as the Spatial Plan of Brčko District are spatial planning documents, namely spatial plans of the highest rank on the territory of Bosnia and Herzegovina.

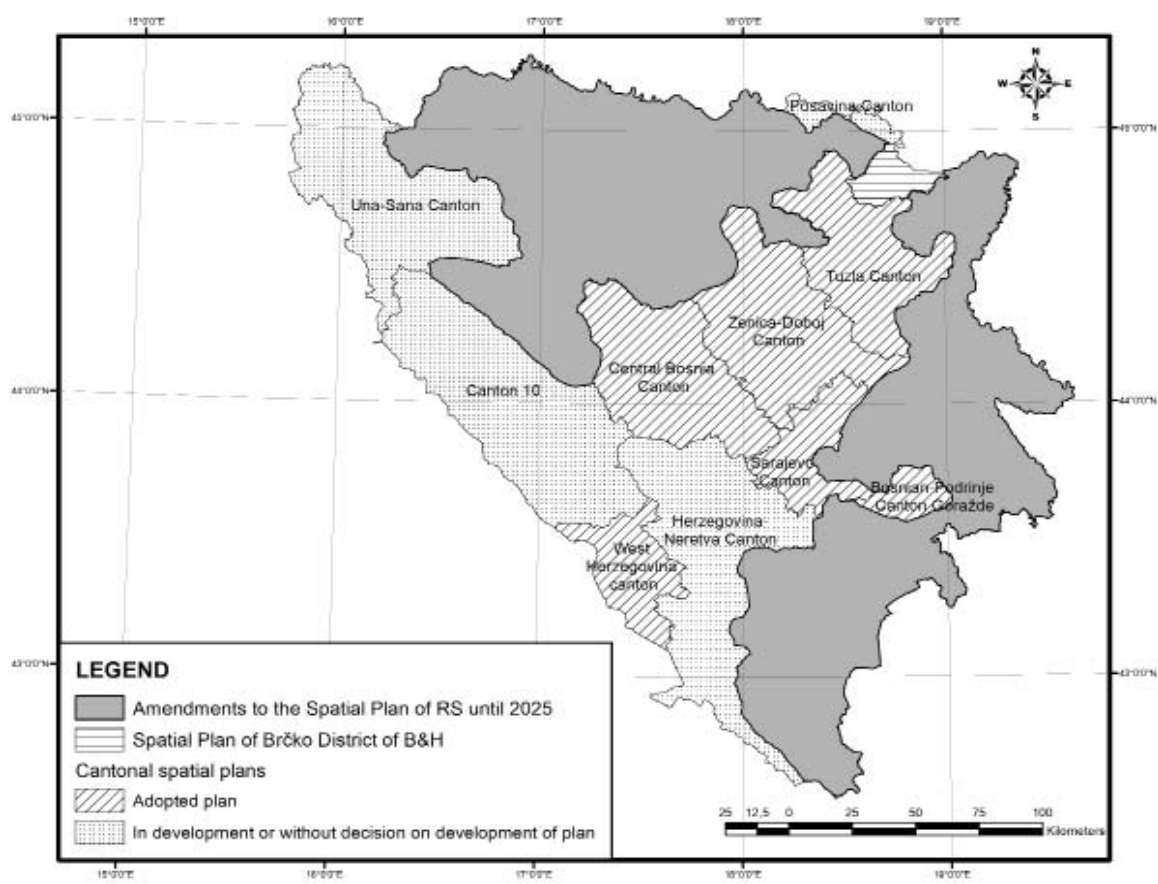

Figure 1. Coverage of the territory of Bosnia and Herzegovina by spatial plans of the highest rank on 31 December 2017

Source: Authors

The table below shows the spatial plans of the highest rank on the territory of Bosnia and Herzegovina adopted by 31 December 2017. These are basic plans, as most of these plans have been amended to a certain extent after their adoption. 
Table 1. Spatial plans of the highest rank on the territory of Bosnia and Herzegovina adopted by 31 December 2017

\begin{tabular}{|l|l|l|}
\hline Entity level spatial plans & \multicolumn{1}{|c|}{ Cantonal spatial plans } & $\begin{array}{c}\text { The Spatial Plan of Brčko } \\
\text { District Bosnia and } \\
\text { Herzegovina }\end{array}$ \\
\hline $\begin{array}{l}\text { Amendments to the } \\
\text { Spatial Plan of the } \\
\text { Republic of Srpska until } \\
2025\end{array}$ & $\begin{array}{l}\text { Spatial Plan of Central Bosnia } \\
\text { Canton 2005 - 2025 }\end{array}$ & $\begin{array}{l}\text { The Spatial Plan of Brčko } \\
\text { District Bosnia and } \\
\text { Herzegovina 2007 - 2017 }\end{array}$ \\
\hline & $\begin{array}{l}\text { Spatial Plan for the Area of Tuzla } \\
\text { Canton 2005-2025 }\end{array}$ & \\
\hline & $\begin{array}{l}\text { Spatial Plan of Sarajevo Canton } \\
\text { for the period 2003-2023 }\end{array}$ & \\
\hline & $\begin{array}{l}\text { Spatial Plan of Zenica - Doboj } \\
\text { Canton (2009-2029) }\end{array}$ & \\
\hline & $\begin{array}{l}\text { Spatial Plan of West } \\
\text { Herzegovina Canton for the } \\
\text { period 2012-2032 }\end{array}$ & $\begin{array}{l}\text { Spatial Plan of Bosnian - } \\
\text { Podrinje Canton Gorazde for the } \\
\text { period of 20 years }\end{array}$ \\
\hline
\end{tabular}

Source: Authors

Unfortunately, the Spatial Plan of the Federation of Bosnia and Herzegovina for the period 2008-2028 came to a halt at its last hurdle. The House of Representatives of the Parliament of the Federation of Bosnia and Herzegovina adopted the Draft of the Spatial Plan of the Federation of Bosnia and Herzegovina at the resumption of the $32^{\text {nd }}$ regular session held on 9th July 2014. However, the House of Peoples of Bosnia and Herzegovina as the upper house of the Parliament, whose basic task is to protect the national interests of the constitutive nations, has never taken into consideration the Draft of the Plan ("Federal Ministry of Spatial Planning", 2015). According to legal provisions, until this plan has been adopted, the Spatial Plan of Bosnia and Herzegovina for the period 1981 to 2000 shall apply to the extent which is not in contravention with the Constitution of the Federation of Bosnia and Herzegovina (Official Gazette of the Federation of Bosnia and Herzegovina, 2006).

\section{Methodology}

This study is based on the comparative analysis of horizontal compliance of the Amendments to the Spatial Plan of the Republic of Srpska until 2025, most of the adopted cantonal spatial plans and the Spatial Plan of Brčko District Bosnia 
and Herzegovina 2007-2017. Due to the lack of the Spatial Plan of the Federation of Bosnia and Herzegovina, the compliance on the entity level will be assessed through an analysis of the relations between the Amendments to the Spatial Plan of the Republic of Srpska until 2025 and five adopted cantonal plans. Only the Spatial Plan of West Herzegovina Canton will not be taken into consideration, as this canton does not border with the territory of the Republic of Srpska.

A comparative analysis of horizontal compliance comprises a comparison of compliance of the planning solutions of external character of spatial plans for adjacent areas. The planning solutions of external character are the planning solutions that handle the interrelation with the adjacent territories. Those are primarily planning solutions from the field of infrastructure. The rate of mutual compliance of spatial plans for adjacent territories would be shown as the percentage relationship between the number of compliant planning solutions of external character and the total number of the planning solutions of external character. Accordingly, the rate of non-compliance would be the percentage difference between the total number of planning solutions of external character and the number of compliant planning solutions of external character. The non-compliance rate can vary between $0 \%$ and $100 \%$, where $0 \%$ indicates the absence (complete lack) of non-compliance, as $100 \%$ indicates the complete noncompliance of spatial plans for adjacent territories.

\section{Results and discussion}

In its first phase, the research focused on the identification of the planning solutions of external character between the spatial plans for adjacent territories in Bosnia and Herzegovina. The total of 33 such planning solutions were identified, whereas 32 planning solutions were between the Amendments to the Spatial Plan of the Republic of Srpska and cantonal spatial plans, and only one planning solution was between the Spatial plan of Brčko District Bosnia and Herzegovina and the Spatial Plan of Tuzla Canton. The most of individual planning solutions of external character exist between the Spatial Plan of Bosnian - Podrinje Canton Gorazde and the Amendments to the Spatial Plan of the Republic of Srpska, which can be explained by the fact that this canton is almost completely surrounded by the territory of the Republic of Srpska. Subsequently, the compliance rate was assessed in the second phase of the research and the non-compliance rate was determined. The results are shown in the table below. 
Table 2. The non-compliance rate of spatial plans of the highest rank in the territory of Bosnia and Herzegovina on 31 $1^{\text {st }}$ December 2017

\begin{tabular}{|l|c|c|c|}
\hline Spatial plan & $\begin{array}{c}\text { Number of } \\
\text { non-compliant } \\
\text { plans }\end{array}$ & $\begin{array}{c}\text { Total number of } \\
\text { external planning } \\
\text { solutions }\end{array}$ & $\begin{array}{c}\text { Non-compliance } \\
\text { rate } \\
\text { (\%) }\end{array}$ \\
\hline $\begin{array}{l}\text { Spatial Plan of Central Bosnia } \\
\text { Canton }\end{array}$ & 3 & 4 & 75.00 \\
\hline $\begin{array}{l}\text { Spatial Plan for the area of } \\
\text { Tuzla Canton }\end{array}$ & 2 & 2 & 100.00 \\
\hline Spatial Plan of Sarajevo Canton & 4 & 6 & 66.67 \\
\hline $\begin{array}{l}\text { Spatial Plan of Zenica - Doboj } \\
\text { Canton }\end{array}$ & 5 & 8 & 100.00 \\
\hline $\begin{array}{l}\text { Spatial Plan of Bosnian - } \\
\text { Podrinje Canton Gorazde }\end{array}$ & 4 & 6 & 66.67 \\
\hline $\begin{array}{l}\text { The Spatial Plan of Brčko } \\
\text { District Bosnia and }\end{array}$ & $\mathbf{2 6}$ & 33 & 78.79 \\
\hline Herzegovina & & & \\
\hline
\end{tabular}

Source: Authors

The table data shows that the non-compliance rate of spatial plans of the highest rank on the territory of Bosnia and Herzegovina amounts to $78.79 \%$. This rate differs depending on the canton or district. For instance, the rate of noncompliance between the Spatial Plan of Sarajevo Canton and the Amendments to the Spatial Plan of the Republic of Srpska, as well as between the Spatial Plan of Brčko District Bosnia Herzegovina, on the one hand, and the Amendments to the Spatial Plan of the Republic of Srpska and the Spatial Plan of Tuzla Canton, on the other hand, amount to $66.67 \%$; however, all planning solutions of external character between the Spatial Plan of Bosnian - Podrinje Canton Gorazde and the Amendments to the Spatial Plan of the Republic of Srpska, i.e. the Spatial Plan of Tuzla Canton and the Amendments to the Spatial Plan of the Republic of Srpska are non-compliant (non-compliance rate - $100 \%$ ).

Until 1992, such non-compliance rate did not exist on the territory of Bosnia and Herzegovina due to the fact that the former Socialist Republic Bosnia and Herzegovina was a unitary organized federal unit within the Socialist Federal Republic of Yugoslavia. The field of spatial planning was regulated by a single regulatory legislation based on the Law on Spatial Planning. This law provided both horizontal and vertical compliance of spatial and urban plans by means of a single body (Republic Committee for Urban Planning, Construction, Housing 
and Communal Affairs) which was the competent authority to give opinion on the "compliance of these plans with the Spatial Plan of the Republic" (Official Gazette of SR Bosnia and Herzegovina, 1987). The establishment of decentralized structure of Bosnia and Herzegovina in 1995 resulted in the transfer of accountability for spatial planning to entities, cantons and Brčko District. However, the problems of horizontal compliance between the same or similar levels of government have not been carefully considered in the new legislation after 1995. Although all these acts generally speak of mutual compliance of spatial planning documents of the entities, cantons and Brčko District, the lack of an elaborate legal coordination mechanism hinders horizontal compliance of these spatial planning documents. The constitutional and legal aspect is closely related to the political aspect of this problem, i.e. to the lack of political will to create a policy framework in the field of spatial planning at the level of Bosnia and Herzegovina, which would harmonise the most important planning solutions in the field of infrastructure and environmental protection. Nevertheless, there are no constitutional grounds for such a policy. Moreover, the use of the Spatial Plan of Bosnia and Herzegovina from 1989 as a spatial planning document of the highest rank for the whole territory of Bosnia and Herzegovina is essentially impossible, even if it were accepted by all the interested parties in Bosnia and Herzegovina (The Republic of Srpska and Brčko District) due to its obsolescence and outdatedness, and massive changes in the area of Bosnia and Herzegovina since its adoption. This has also led to deviations from its planning solutions in the cantonal spatial plans on the territory of the Federation of Bosnia and Herzegovina, where it was to be used as the plan of the highest rank in the absence of the Spatial Plan of the Federation of Bosnia and Herzegovina.

\section{Conclusion}

The conducted research of the non-compliance rate of planning solutions of external character has undoubtedly confirmed the basic hypothesis of this paper that the non-compliance rate of spatial plans of the highest rank for adjacent areas in Bosnia and Herzegovina is above 50 \%, i.e. that there are more non-compliant planning solutions of external character than compliant ones among these documents. The causes of this phenomenon can be found both in the legal and in the political framework. From the legal point of view, the lack of an elaborate legal coordination mechanism hinders the horizontal compliance of spatial planning documents of the entities, cantons and Brčko District. As regards politics, there is no will to create a policy framework in the field of spatial planning at the level of Bosnia and Herzegovina, which would harmonise the most important planning solutions in the fields of infrastructure and environment protection 
on the whole territory of Bosnia and Herzegovina. The auxiliary hypothesis has been thus verified as well, which put the non-compliance of spatial plans in relation with the inadequate regulation of the matter and the lack of the policy framework in the field of spatial planning in Bosnia and Herzegovina as a document which would harmonise the planning solutions of common interest for both entities and for Brčko District, i.e. for the whole Bosnia and Herzegovina.

The development of a policy framework in the field of spatial planning at the level of Bosnia and Herzegovina and the definitions of an elaborate coordination mechanism within the existing legislation would optimally reduce the current enormous non-compliance rate $(78.79 \%)$ among the spatial plans of the highest rank in Bosnia and Herzegovina.

\section{References}

Alexander, R.E. (2000). Approaches to planning: Introducing Current Planning Theories, Concepts and Issues (Second Edition). Philadelphia: Gordon and Breach Science Publishers.

Bublin, M. (2000). Prostorno planiranje. Sarajevo: Univerzitetska knjiga.

Đorđević, D., \& Dabović, T. (2009). Osnove prostornog planiranja. Beograd: Univerzitet u Beogradu - Geografski fakultet.

Faludi, A. (2000). The Performance of Spatial Planning. Planning Practice \& Research, Vol. 15(4), pp. 299-318.

Federalno ministarstvo prostornog uređenja. (2015). Prostorni plan: aktivnosti na izradi Prostornog plana Federacije Bosne i Hercegovine. Retrieved from http:/ / www.fmpu.gov.ba/prostorni-plan-fbih

Kanton Sarajevo. (2006). Prostorni plan Kantona Sarajevo za period od 2003. do 2023. godine. Sarajevo: Zavod za planiranje razvoja Kantona Sarajevo, Vlada Kantona Sarajevo.

Kanton Središnja Bosna - Srednjobosanski kanton. (2005). Prostorni plan Kantona Središnja Bosna/Srednjobosanskog kantona 2005. - 2025. Sarajevo/Zagreb: Institut za arhitekturu, urbanizam i prostorno planiranje Sarajevo, Arhitektonski fakultet Sveučilište u Zagrebu.

Novi urbanistički zavod RS. (2015). Izmjene i dopune Prostornog plana Republike Srpske do 2025.godine. Banja Luka: Novi urbanistički zavod RS.

Piha, B. (1979). Osnove prostornog planiranja. Univerzitet u Beogradu: Beograd.

Politika u oblasti prostornog planiranja. (2012). Projekat upravne odgovornosti (GAP).

Procjene rizika od poplava i klizišta za stambeni sektor u Bosni i Hercegovini. (2015). EU program oporavka od poplava. 
Skupština SR BiH. (1989). Prostorni plan Bosne i Hercegovine za period od 1981. do 2000. godine (prečišćeni tekst). Sarajevo: Skupština Socijalističke Republike Bosne i Hercegovine.

Službene novine Federacije Bosne i Hercegovine. (2006). Zakon o prostornom planiranju i korištenju zemljišta na nivou Federacije Bosne i Hercegovine ("Službene novine FBiH", br. 2/06, 72/07, 32/08, 4/10, 13/10 i 45/10). Sarajevo: Službene novine Federacije Bosne i Hercegovine.

Službene novine Zeničko - dobojskog kantona. (2009). Prostorni plan Zeničko dobojskog kantona (2009 - 2029.) ("Službene novine ZDK", br. 4/09). Zenica: Službene novine Zeničko - dobojskog kantona.

Službene novine Tuzlanskog kantona. (2006). Prostorni plan za područje Tuzlanskog kantona 2005-2025. («Službene novine TK», br. 9/06). Tuzla: Službene novine Tuzlanskog kantona.

Službeni list Socijalističke Republike Bosne i Hercegovine. (1987). Zakon o prostornom uređenju ("Službeni list SR BiH", br. 9/87). Sarajevo: Službeni list Socijalističke Republike Bosne i Hercegovine.

Urbis centar. (2016). Prostorni plan za područje Bosansko - podrinjskog kantona Goražde za period od 20 godina. Banja Luka: Urbis centar d.o.o.

Veneto Progetti, Synerghia. (2008). Prostorni plan Brčko distrikta. Treviso/Milano: Veneto Progetti S.C., Synerghia S.p.A.

Vlada Federacije BiH. (2013). Prostorni plan Federacije BiH za period 2008.-2028. godine (prijedlog). Sarajevo: Vlada Federacije Bosne i Hercegovine.

Vlada Županije Zapadnohercegovačke. (2013). Prostorni plan Županije Zapadnohercegovačke za period od 2012. do 2032. godine. Široki Brijeg: Vlada Županije Zapadnohercegovačke. 